\title{
KEBIJAKAN KRIMINAL DALAM MENANGGULANGI KENAKALAN REMAJA
}

\begin{abstract}
Abdul Kholiq ${ }^{*}$
ABSTRACT

Youth are the future leaders of a nation. In addition to things that have been encouraging with the activities of teenagers lately such as increasingly actively participating in student organizations and increasing achievement, we also see the flow of moral decline that is increasingly prevalent among some of our young people, who are better known as delinquency. adolescents such as student fights, narcotics distribution, drug use, liquor, snatchers and so forth. Cases of juvenile delinquency can be influenced by several factors, namely family factors, school factors, community factors and economic factors, and therefore need to be addressed separately. The countermeasures are in the form of non-penalties that can be carried out individually and socially, preventively, by non-governmental organizations and also by the government, in addition to countermeasures also in the form of penalties, namely by giving sanctions.
\end{abstract}

Keywords: Policy, Crime, Juvenile Delinquency,

\section{PENDAHULUAN}

Remaja adalah masa peralihan dari kanak-kanak ke dewasa. Seorang remaja sudah tidak lagi dapat dikatakan sebagai kanak-kanak, namun ia masih belum cukup matang untuk dapat dikatakan dewasa. Ia sedang mencari pola hidup yang paling sesuai baginya dan inipun sering dilakukan melalui metode coba-coba walaupun melalui banyak kesalahan. Kesalahan yang dilakukannya sering menimbulkan kekawatiran serta perasaan yang tidak menyenangkan bagi lingkungannya, orangtuanya. Kesalahan yang diperbuat para remaja hanya akan menyenangkan teman sebayanya. Hal ini karena mereka semua memang sama-sama masih dalam masa mencari identitas. Kesalahankesalahan yang menimbulkan kekesalan lingkungan inilah yang sering disebut sebagai kenakalan remaja.

* Abdul Kholiq adalah Pengajar di Universitas 17 Agustus 1945 Semarang dapat dihubungi melalui email : abdulkholiqsh@gmail.com
Remaja merupakan pemimpin masa depan suatu bangsa. Di samping hal-hal yang menggembirakan dengan kegiatan remaja-remaja akhir-akhir ini seperti semakin aktif mengikuti organisasi antar pelajar dan peningkatan prestasi, kita melihat pula arus kemorosotan moral yang semakin melanda di kalangan sebagian pemuda-pemuda kita, yang lebih terkenal dengan sebutan kenakalan remaja. Dalam surat kabar-surat kabar sering kali kita membaca berita tentang perkelahian pelajar, penyebaran narkotika, pemakaian obat bius, minuman keras, penjambret yang dilakukan oleh anak-anak yang berusia belasan tahun, meningkatnya kasus-kasus kehamilan di kalangan remaja putri dan lain sebagainya.

Hal tersebut adalah suatu masalah yang dihadapi masyarakat yang kini semakin marak, oleh karena itu masalah kenakalan remaja seyogyanya mendapat kan perhatian yang serius dan terfokus untuk mengarahkan remaja ke arah yang lebih positif, yang titik beratnya untuk 
terciptanya suatu sistem dalam menanggulangi kenakalan di kalangan remaja.

Pengertian remaja pada umumnya adalah muda-mudi kita yang masih dianggap sebagai anak-anak, misalnya apabila kita lihat dari segi pengertian atau pendirian masyarakat secara umum, biasanya usia mereka antara 13 tahun sampai dengan 15 tahun (belum kawin). Dan bila dilihat dari segi umur, mungkin mereka seperti orang dewasa, akan tetapi dalam bertingkah laku sesungguhnya mereka masih harus belajar banak, baik melalui pendidikan orang tua maupun pengalaman-pengalaman dalam kehidupan.

"Apabila kita menyimak pada isi KUHPerdata, pada pasal 330 menerangkan bahwa yang dikategorikan sebagai belum dewasa adalah bagi mereka yang sudah berumur 21 tahun dan itupun harus belum pernah menikah".

Dari segi agama maupun segi adat pada umumnya yang dikatakan sudah dewasa adalah mereka yang jika wanita sudah pernah haid dan jika laki-laki sudah pernah mengeluarkan sperma dalam keadaan tidak sadar, suaranya berubah menjadi besar. Sedangkan dalam "KUHP pada pasal 45 , diatur bahwa yang dianggap belum dewasa adalah bagi mereka yang umurnya belum mencapai 16 tahun" ${ }^{2}$

Sedemikian banyaknya pendapatpendapat yang saling berbeda-beda yang satu dengan yang lain, seperti yang penulis uraikan diatas, adalah suatu bukti bahwa betapa pentingnya untuk memahami pengertian tentang anak-anak atau remaja. Hal ini karena sangat berkaitan erat nantinya dengan proses peradilan atau penanggulangan tindak pidana yang dilakukan oleh anak-anak dan remaja .

1 R. Subekti, dan R. Tjipto Sudibyo, KUHP Perdata, PT. Pradaya Paramita, Jakarta, 1986, hlm. 98.

2 R. Soesilo, KHUP, PT. Karya Nusantara, Bandung, 1983, hlm. 61
Sehubungan dengan proses peradilan pidana anak-anak, kita dapat melihat undang-undnag tentang peradilan anak-anak, dimana pada pasal 1 ayat (1) dinyatakan bahwa yang dimaksud dengan anak-anak nakal:

a. Yang melakukan tindak pidana.

b. Yang tidak dapat diatur dan tidak taat kepada orang tua atau wali atau pengasuh.

c. Yang sering meninggalkan rumah, tanpa izin atau pengetahuan orang tua atau wali atau pengasuh.

d. Yang bergaul dengan penjahat-penjahat atau orang-orang tidak bermoral, sedang anak tersebut mengetahui hal itu.

e. Yang kerap kali mengunjungi tempattempat terlarang bagi anak-anak.

f. Yang sering menggunakan kata-kata kotor.

g. Yang melakukan tindakan atau perbuatan yang mempunyai akibat yang tidak baik bagi perkembangan pribadi, social rohani dan jasmani anak itu. ${ }^{3}$

Dari uraian Undang-Undang seperti yang diuraikan di atas, tampak bahwa konsep tersebut menganut penggunaan istilah dari "Juvenile delinquency", yang didalamnya meliputi pula tindak pidana yang dilakukan oleh anak-anak. Sehingga dapat disimpulkan bahwa kejahatan anakanak merupakan bagian dari kenakalan anak-anak. Dalam istilah yang lazim, perkataan "Juvenile" sering dipergunakan sebagai istilah lain dari anak-anak. Terhadap istilah ini ada dua penafsiran dalam pengertiannya: pertama pengertian anak-anak untuk pertimbangan aparat penegak hukum (polisi, jaksa, hakim dalam rangka menerapkan kebijakan pidana pada proses peradilan anak-anak.

Dari yang pertama ini, dimaksud kan hanya untuk membedakan antara pelaku tindak pidana yang masih anak-anak

3 Prof. Sudarto, S.H., Kapita Selekta Hukum Pidana. Alumni Bandung, 1981, hlm. 135. 
(non adult offender) dengan pelaku tindak pidana yang sudah dewasa (adult offender). Tentang "Juvenile" ini, Romli Atmasasmita mengemukakan pendapat dengan mengata kan. "Pada umumnya yang diartikan Juvenila itu adalah seorang anak yang masih di bawah usia tertentu dan belum dewasa serta belum kawin. ${ }^{4}$

Kemudian pengertian yang kedua adalah pengertian sebagai remaja.. sebutan ini biasanya didasarkan atas kondisi psikologis seseorang, dimana pada usia belasan tahun sering di sebut sebagai remaja. Namun demikian pengertian inipun tidak semua orang dapat menerimanya, karena pengertian "Juvenile" terlalu umum dan mencakup semua orang yang masih muda usianya.

Demikian halnya dengan pendapat yang dikemukakan oleh Sri Widoyanti Wiratno Sukito, dalam bukunya yang berjudul "Anak dan wanita dalam hukum" mengatakan bahwa :

"Kenakalan remaja berarti hal-hal yang berbeda dalam golongan yang sama, pada waktu yang berbeda. Dalam penggunaan yang popular, pengertian kenakalan remaja digunakan untuk melukiskan sejumlah besar tingkah laku anak-anak dan remaja yang tidak baik atau yang tidak disetujui. Dalam pengertian ini, hampir segala sesuatu yang dilakukan oleh remaja yang tidak disukai oleh orang lain disebut sebagai kenakalan remaja".

Dikalangan masyarakat, suatu tindak pidana yang dilakukan oleh anakanak, biasa disebut sebagai kenakalan remaja. Kenakalan dalam hal ini, adalah suatu perbuatan yang mengandung unsurunsur perbuatan tercela yang dapat dianggap sebagai pelanggaran terhadap

4 Romli Admasasmita, SH, LL.M, Problem Kenakalan Anak-anak atau Remaja (Yuridis Sosio Kriminologis), Armico, Bandung, 1986, hlm. 25.

5 Sri Widoyanti Wiratni Sukito, Anak dan Wanita dalam Hukum, LP3ES, Jakarta, 1983, hlm. 9 dan 10. hukum dan atau mengandung unsur-unsur tindak pidana, minimal perbuatan tersebut dapat menganggu ketentraman terhadap seseorang, keluarga atau masyarakat disekitarnya dan secara maksimal dapat dianggap merupakan salah satu bentuk gangguan terhadap keamanan dan ketertiban masyarakat, bahkan dapat pula dianggap merupakan masalah nasional.

\section{PERMASALAHAN}

Dari latar belakang tersebut dapat dirumuskan permasalahan sebagai berikut:

1. Faktor-faktor apa yang menyebabkan terjadi kenakalan remaja?

2. Bagaimana kebijakan kriminal dalam menanggulangi kenakalan remaja?

\section{PEMBAHASAN}

\section{Faktor-faktor yang menyebabkan terjadi kenakalan remaja}

Pada masa ini jumlah dan jenis kejahatan atau kenakalan anak/remaja semakin meningkat. Untuk mengetahui lebih jauh tentang kenakalan remaja, perlu melihat faktor-faktor yang melatar belakanginya, yaitu:

\section{Faktor keluarga}

Keluarga merupakan wadah pembentuk an pribadi anggota keluarga terutama anak-anak yang sedang mengalami pertumbuhan fisik dan rohani. Dengan demikian kedudukan keluarga sangat fundamental dan mempunyai peranan yang sangat vital bagi pendidikan seorang anak. Lingkungan keluarga secara potensial dapat membentuk pribadi anak atau seseorang untuk hidup secara lebih bertanggungjawab. Tetapi apabila usaha pendidikan dalam keluarga itu gagal akan terbentuk seorang anak yang cenderung melakukan tindakan kenakalan dalam 
masyarakat dan sering menjurus kepada tindakan kejahatan atau kriminal. Disamping itu juga kenakalan anak/remaja disebabkan karena:

A. Keluarga yang broken home

a. Orang tua bercerai.

b. Unit keluarga yang tidak lengkap karena hubungan di luar pernikahan.

c. Tidak adanya komunikasi yang sehat dalam keluarga.

d. Kematian salah satu orang tua atau keduanya bisa berakibat fatal jikalau masa depan anak menjadi terlantar, kurang mendapat kasih sayang, dan tidak memperoleh tempat bergantung hidup yang layak.

e. Adanya ketidakcocokan atau persesuaian antara pihak orang tua dan senantiasa berada dalam suasana perselisihan/konflik karena faktor perbedaan agama perbedaan norma, ambisi orang tua.

B. Pendidikan yang salah

a. Over proteksi dari orang tua

Ada orang tua yang mempunyai anggapan dan sikap yang menginginkan agar anaknya tidak mengalami hidup susah, maka ia senantiasa memenuhi / memberikan segala permintaan anak akan barang-barang mewah dengan harapan anak menjadi terhibur dan ikut merasakan kasih sayang orang tua. Tetapi dengan tindakan tersebut justru mengakibatkan anak tidak mampu mencapai kematangan pribadi, malas untuk mengurus keperluan hidupnya sendiri, selalu bergantung pada orang lain, menjadi anak yang lemah mental, tidak memiliki inisiatif diri atau harga diri. Tindakan mereka cenderung sewenang- wenang, memaksakan kehendak dan kemauannya, egoistis dan tindakan yang tidak wajar lainnya yang sering bertentang dengan norma susila dan hukum.

b. Kurang ditanamkan oleh orang tua, seperti misalnya nilai-nilai kehidupan/norma religus dan sebagainya.

c. Terjepitnya generasi muda antara norma-norma baru, menyebabkan mereka tidak mempunyai pegangan untuk menilai semua sikap dan tingkah lakunya, sebab semua nya serba relative dan kabur. Sedangkan bimbingan dari pihak orang tua kurang. Hal ini mencenderungkan anak/remaja bersikap tertutup dengan orang tua dan komunikasi terbatas pada suasana normal dan hanya basa-basi belaka.

d. Anak yang ditolak

Penolakan anak yang diakibat kan oleh suami-isteri yang tidak dewasa secara psychis, sehingga tidak mau ber tanggungjawab sebagai ayah dan ibu. Dan juga apabila anak mempunyai cacat tubuh atau bentuk tubuh yang jelek, sehingga orang tua menjadi malu. Akibatnya anak-anak yang ditolak tersebut akan merasa diabaikan, terhina dan malu sehingga dapat me lampiaskannya untuk berbuat yang tidak baik atau melanggar hukum.

\section{Faktor Sekolah}

Sekolah merupakan tempat pendidikan formal yang mempunyai peranan penting untuk mengembangkan kepribadian anak sesuai dengan 
kemampuan dan pengetahuannya. Untuk nantinya dapat melaksanakan tugas di masyarakat. Tujuan ini dapat berhasil apabila dari pihak pendidik (guru) mampu mendorong dan mengarahkan muridmuridnya untuk belajar mengembangkan kreatifitas pengetahuan dan ketrampilan nya. Artinya antara guru dan murid ada hubungan yang baik dan saling mem percayai untuk belajar bersama. Tetapi yang sering terjadi adalah sebaliknya, dengan kondisi sekolah yang tidak menguntungkan perkembangan jasmani dan rohani anak, dimana pendidikan dewasa ini ternyata masih kurang memberi tempat dialog dalam arti yang sebenarnya, yaitu murid harus menelan semua kehendak guru tanpa memperhatikan minat, bakat dan kemampuan murid, dan juga karena kurikulum yang selalu berubah-ubah sehingga mengacaukan murid, dan juga karena kurikulum yang selalu berubahubah sehingga mengacaukan murid dan guru, materi pelajaran yang dangkal dan tidak menarik dan ditambah dengan adanya sikap guru yang kurang simpatik, tidak sabar, mudah tersinggung, tidak bersahabat dan sebagainya. Akibatnya timbul kekecewaan pada murid-murid tanpa mempunyai semangat dan ketekunan di dalam belajar. Lalu timbulah model membolos, santai-santai mengganggu dengan kenakalan yang tidak jarang merupakan tindakan kriminal.

\section{Faktor Masyarakat}

Lingkungan tempat anak berpijak sebagai makhluk sosial ialah masyarakat. Manusia sebagai makhluk sosial tidak bisa melepaskan diri dari masyarakatnya. Anak dibentuk oleh masyarakat dan dia juga sebagai anggota masyarakat membutuhkan masyarakat. Oleh sebab itu kalau pembentukan masyarakat itu baik maka membawa anak kepada pembentukan tingkah laku yang baik pula. Lingkungan yang tidak baik dapat membuat kelakuan seseorang menjadi tidak baik dapat membuat kelakuan seseorang menjadi tidak baik (jahat) karena anak-anak sifatnya suka meniru-niru. Demikian juga karena adanya pengaruh dari kebudayaan lain melalui media massa, misalnya melalui film, TV, Video, cassette, buku-buku atau majalah dan surat kabar. Memang secara positif media massa ini berperan besar untuk mengembangkan ilmu pengetahuan atau teknologi, kemajuan ilmu pendidikan dan sebagainya. Akan tetapi media massa ini juga dapat dipakai untuk menanamkan pengaruh yang negatif pada masyarakat; misalnya film-film porno, buku-buku cabul, film kekerasan dan lain-lain. Pengaruh buruk atau baik bisa secara langsung atau tidak langsung terhadap anak.

\section{Faktor-Faktor Ekonomi}

Besarnya jumlah keluarga dalam satu keluarga dan ketidakmampuan memenuhi dan menunjang kebutuhan anakanak merupakan salah satu sebab yang membuat anak-anak merasa tidak aman. Dan anak-anak yang tidak merasa aman di rumah karena kemiskinan sangat merusak konsep anak itu akan arti hidup ini. Dan hal itu akan membuat dia merasakan harga diri yang snagat rendah dihadapan teman dan kawan-kawan sekelasnya. Frustasi atau kejengkelan-kejengkelan yang disebabkan ketidakmampuan orang tua dalam memenuhi kebutuhannya itu, akan disalurkan pada tindakan-tindakan yang negatif. Mungkin karena ketidakmampuan orang tua membayar biaya pendidikan, membuat si anak mandek di tengah jalanalias drop out, kemudian putus asa dan menilai hidup ini tidak berarti sama sekali. Ketidakmampuannya dalam menilai hidup ini mendorong dia nekat melakukan kejahatan. 


\section{Kebijakan kriminal dalam menanggulangi kenakalan remaja.}

Kebijakan kriminal merupakan bagian dari kebijakan penegakan hukum (law enforcement policy) yang mencakup kebijakan hukum pidana, hukum perdata, dan hukum administratif, yang secara keseluruhan merupakan bagian dari politik sosial (social policy), yang merupakan usaha dari suatu masyarakat untuk meningkatkan ketahanan sosialnya (social resilience) yang meliputi kesejahteraan dan ketahanan sosialnya. ${ }^{6}$ Kebijakan kriminal untuk menanggulangi kenakalan remaja dapat dilakukan dengan cara : pencegahan tanpa pidana (prevention without punishment), mempengruhi pandangan masyarakat mengenai kejahatan dan pemidanaan lewat mass media (influencing views of society on crime and punishment atau mass media) dan penerapan hukum pidana (criminal law application). Dari tiga jenis penanggulangan terebut dua yang pertama dikategorikan sebagai non penal (non pidana) dan yang terakhir dikategorikan sebagai penal (pidana).

\section{Penanggulangan Non Penal} meliputi :

Penanggulangan non penal ini

\section{a. Penanggulangan Individual dan Sosial}

Penanggulangan individual dilaku kan dengan mengadakan perbaikanperbaikan pada pelaku kenalan remaja, sedangkan penanggulangan sosial merupakan penanggulangan yang bersifat umum. Dalam penanggulangan individual sosial meliuti antara lain :

a.1 Disiplin Keluarga

Keluarga merupakan lingkungan

6 Muladi dan Diah Sulistyani RS, Kompleksitas perkembangan tindak pidana dan kebijakan kriminal, Alumni, Bandung, 2016, hlm. 154. pertama yang dikenal anak. Oleh karena itu peran serta orang tua dalam mendidik dan menerapkan disiplin pada anak sangat dominan, sehingga tercapai suatu keluarga yang tentram dan damai. Dengan demikian perkembangan anak diketahui dan dipahami oleh orang tua, emosi anak terkendali dan anak betah tinggal di rumah. Dengan kata lain tidak ada alasan lagi bagi anak untuk melakukan hal-hal yang melanggar norma yang berlaku di masyarakat. Disini komunikasi antara orang tua dan anak sangat penting sekali.

\section{a.2 Displin Sekolah}

Disiplin sekolah merupakan lingkungan kedua bagi anak, maka segala fasilitas dan prasarana untuk terselenggarakannya proses belajar mengajar harus bersedia. Dengan demikian anak diharapkan betah tinggal di sekolah dan bisa belajar dengan tenang. Dalam pelaksanaan proses belajar mengajar, sebaiknya guru mempergunakan metode penelitian berdasarkan kasih sayang, agar anak didik tunduk dan patuh. Untuk mengetahui perkembangan anak didik perlu adanya kerjasama antara guru dan orang tua atau wali murid. Untuk pembentukan moral pada anak didik, peran serta guru agama sangat dominan. Di sini peran guru sangat penting bagi anak didik, untuk itu ada slogan : Ing Ngarso Sung Tulodho, ing Madyo Mangun Karso, Tut Wuri Handayani. Slogan ini harus benar-benar diterapkan, sehingga apa yang menjadi tujuan pendidikan di sekolah dapat tercapai.

\section{a.3 Disiplin Lingkungan}


Masyarakat adalah tempat pendidikan ke tiga sesaudah rumah dan sekolah. Ketiganya harus mempunyai keseragaman dalam mengarahkan anak untuk tercapai nya tujuan pendidikan. Tingkah laku orang dewasa di dalam masyarakat merupakan contoh pendidikan bagi anak-anak yang sedang dalam proses perkembang an. Jika tingkah laku manusia dalam masyarakat sebagian besar telah rusak, maka disiplin rumah dan sekolah akan sia-sia. oleh karena itu kehidupan dalam masyarakat harus pula diusahakan agar menjadi lebih baik bahkan menanamkan suatu disiplin, sehingga anak-anak dapat mematuhi dan mencegah timbulnya penganiayaan terhadap anak. Disini peran pemuka masyarakat sangat lah penting, mengikut sertakan warga masyarakat ke dalam kegiatan sosial. Dan penyediaan waktu oleh pemuka agama dan pemuka masyarakat untuk mengada kan dialog dengan warga.

\section{a.4 Displin Jalan}

Di dalam displin jalan, para petugas kepolisian dapat menanamkan melalui pengarahan-pengarahan baik secara langsung maupun melalui penyuluhan-penyuluhan. Dengan cara ini dimungkinkan dapat mengurangi terjadinya kenakalan remaja. ketaatan dan kepatuhan di jalan berarti penanaman disiplin pada peraturan.

\section{b. Penanggulangan preventif}

b.1 Metode yang digunakan untuk pencegahan terhadap kenakalan remaja adalah melalui disiplin keluarga, disiplin sekolah, disiplin lingkungan dan disiplin jalan. Di mana semuanya bertujuan untuk menegakan kedisplinan masyarakat.

b. 2 pembinaan mental dan penanaman agama sangat penting bagi masyarakat, sehingga masyarakat bisa menghindarkan diri dari perbuatan yang melanggar hukum, misalnya dengan menjadikan tempat ibadah sebagai tempat pusat kegiatan keagamaan.

b.3 Peran serta orang tua, guru, pemuka agama, pemuka masyarakat dan penegak hukum sangat penting bag perkembangan anak. Untuk itu penegakan falsafah Ing Ngarso Sung Tulodho, Ing Madyo Mangun Karso, dan Tut Wuri Handayani dapat diterapkan.

b.4 Mengikut sertakan anggota masyarakat dalam kegiatan sosial, sangat membantu pencegahan kenakalan remja, karena disini ditanamkan dan diajarkan cinta kasih terhadap sesama manusia.

b.5 Dialog antara anak dan orang tua merupakan jembatan emas dalam penciptaan keluarga yang aman, tentram dan bahagia sehingga anak tumbuh secara wajar dan sehat serta terhindar dari perbuatan-perbuatan yang tercela.

\section{c. Penanggulangan Yang dilakukan Lembaga Swadaya masyarakat}

Penanggulangan sejumlah Lembaga Swadaya Masyarakat dikenal melaksanakan beberapa agenda program yang berkaitan dengan kenakalan remaja. Namun demikian mereka yang terlibat dalam program penanganan langsung masalah ini sangatlah terbatas. Sebuah program lembaga swadaya masyarakat yang diketahui memberikan secara langsung kepada anak-anak atau remaja adalah :

1. Memperkuat usaha yang telah berjalan 
untuk menyediakan kesempatan pendidikan kepada anak-anak khususnya pendidikan dasar.

2. Menyusun dan meningkatkan serta mengimplementasikan kebijakan sosial, ekonomi dan program nasional yang sensitive jender untuk membantu kenakalan remaja. dengan perhatian khusus diberikan terhadap remaja atau anak.

3. Mempromosikan cara-cara untuk memperkuat ikatan keluarga demi terbentuknya lingkungan yang sehat bagi perkembangan anak serta mempromosikan hak-hak anak dalam pendidikan keluarga dan bimbingan pengembangan keluarga, termasuk pemahaman bahwa kedua orang tua sangat besar tanggungjawab dalam hal pendidikan dan pengasuhan anak, serta melakukan intervensi khusus untuk menghindarkan diri dari kenakalan remaja.

4. Peningkatan kesadaran pada anak, keluarga dan masyarakat mengenai konsekwensi dari kenakalan.

5. Memberikan penyadaran kepada masyarakat melalui pendekatanpendekatan atau dengan kegiatankegiatan sosial.

\section{d. Penanggulangan Oleh Pemerintah}

Langkah-langkah yang diambil oleh pemerintah dalam menyikapi semakin meningkatnya kenakalan remaja di antaranya adalah:

a. Keluarnya Undang-Undang Nomor 35 tahun 2014 tentang Perlindungan Anak yang lebih condong merujuk pada Konvensi Hak Anak (KHA) sehingga dapat sesuai dengan perkembangan internasional tentang penanganan kasus yang melibatkan anak.

b. Pembentukan Unit Ruang Pelayanan Khusus (RPK) oleh kepolisian Republik Indonesia yaitu : sebuah ruang pelayanan khusus yang tertentu dan aman di kesatuan Polisi Republik Indonesia, Ruang Pelayanan Khusus dalam melaksanakan tugasnya bekerja sama dengan rumah sakit, laboratorium forensic, psikolog, penasehat hukum dan lembaga swadaya masyarakat. Pemerintah atas desakan masyarakat dan lembaga swadaya masyarakat yang konsen terhadap permasalahan kenakalan remaja juga telah mengeluar kan beberapa peraturan untuk membendung dan menanggulangi permasalahan kenakalan remaja.

c. Memperat kerjasama dan interaksi antar lembaga antar sektor termasuk lembaga non pemerintah, kelompok keagamaan, akademis dan sektor lain dalam masyarakat madani termasuk lembaga yang menangani tentang hak asasi manusia.

d. Memperkuat penegakan hukum yaitu dengan adanya Undang-Undang Nomor 35 Tahun 2014 tentang perlindungan anak.

e. Menyediakan konseling sosial, medis dan psikologis serta bantuan lain kepada anak yang menjadi korban tindak pidana kekerasan serta dengan sudut pandang yang mendorong tumbuhnya rasa kehormatan pribadi, harga diri (dignity) dan hak-hak anak-anak. Melakukan cara yang tidak menghukum dan manusiawi sehingga hukum yang harus ditempuh anak tidak semakin memperburuk traumanya tentang kekerasan.

\section{Penanggulangan Penal}

1. Upaya penanggulangan dengan cara penal (penegakan hukum pidana), sangat efektif untuk dapat dijadikan shock terapi bagi orang lain untuk tidak melakukan kejahatan. Tetapi upaya penal dengan penerapan sanksi pidana, baik pidana penjara maupun pidana denda belum dapat menjamin turunkan angka statistik 
kejahatan. Usaha penindakan (Represif), yaitu usaha untuk menyembuhkan kenakalan remaja atau anak-anak dengan melalui :
a. Pemeriksaan anak-anak nakal
b. Penahanan anak-anak nakal
c. Pengajuan anak-anak ke pengadilan anak-anak
d. Pengusutan perkara kenakalan anak
Apabila anak tersebut masih bisa diperbaiki, maka anak tersebut akan diserahkan kepada pihak keluarganya dengan membuat surat pernyataan, bahwa mereka bersedia untuk mendidik anaknya agar tidak mengulanginya perbuatannya lagi, karena bagaimanapun peran keluarga lebih menentukan daripada usaha yang dilakukan oleh masyarakat, sekolah dan pemerintah.

Guna daripada surat pernyataan adalah apabila suatu waktu anak tersebut melakukan tindak pidana lagi, maka kepadanya dapat ditindak secara hukum. Akan tetapi bila anak tersebut sudah tidak dapat diperbaiki lagi dalam arti ia sudah tidak dapat dibina lagi oleh pihak keluarganya, departemen sosial dan sebagainya dan bahkan ia mengulangi perbuatannya atau tindak pidananya, maka pihak penegak hukum tidak segan-segan menindak secara hukum, misalnya : Memberikan sanksi pidana sesuai dengan kejahatan yang dilakukannya kepada para tersangka.

\section{Kesimpulan}

Berdasarkan pembahasan dari uraian yang telah dipaparkan pada bagian depan tulisan ini, maka secara umum dapat disimpulkan sebagai berikut :

1. Faktor yang menyebabkan terjadinya kenakalan remaja adalah faktor keluarga, faktor sekolah, faktor masyarakat dan faktor ekonomi.

2. Kebijakan kriminal dalam menang gulangi kenakalan remaja dengan cara non penal dan penal.

\section{Daftar Pustaka}

Muladi dan Diah Sulistyani RS, Kompleksitas perkembangan tindak pidana dan kebijakan kriminal, Alumni, Bandung, 2016

Romli Admasasmita, SH, LL.M, Problem Kenakalan Anak-anak atau Remaja (Yuridis Sosio Kriminologis), Armico, Bandung, 1986

R. Soesilo, KHUP, PT. Karya Nusantara, Bandung, 1983

R. Subekti, SH dan R. Tjipto Sudibyo, KUHP Perdata, PT. Pradaya Paramita, Jakarta, 1986

Sri Widoyanti Wiratni Sukito, Anak dan Wanita dalam Hukum, LP3ES, Jakarta, 1983

Sudarto, Kapita Selekta Hukum Pidana. Alumni Bandung, 1981 